\title{
The Legal Liability of Dead Children Drowns in Coal Mine Pit on Human Rights Perspective
}

\author{
Haris Retno Susmiyati ${ }^{1}$ \\ \{harisretno@yahoo.co.id ${ }^{1}$ \} \\ Law Faculty of Mulawarman University, Samarinda, East Kalimantan Province, Indonesia ${ }^{1}$
}

\begin{abstract}
Children who live in Kalimantan, especially in Samarinda, Kutai Kartanegara and Paser Regency, should be in an unsafe situation due to economic policies that based on exploitation of coal mine. Since 2010 - 2017 there were 28 victims, 26 children and 2 adult drowned in coal mine pit. However, the legal process of this case is unfair or far from the sense of justice for the victims and people, when the case was happening, the mining company approach to the victim's family for granting sum of money in return for a statement letter that it would not prosecute the drowning of children in the coal mine pit. Two cases were settled legally but those filed to the trial are field workers and punished lightly. The legal liability has not touched the responsible person of the business. The case of children drowning in coal pit, under national and international human rights provitions/instruments is a violation of the child rights, especially the fundamental right of the child that is the right to life. The removal of a person's right to life is a crime against humanity. The rights of the child that being violated are (1) The Right to Life; (2) The Right to Live Safe; (3) The Right to Obtain the Legal Protection; (4) The Right to a Healthy Environment; (5) The Right to equal and Equality in Law. The fast and concrete steps must be taken by the state to provide the sense of justice and prevent further casualties.
\end{abstract}

Keywords: Mining, Coal, Liability, Child, Human Rights

\section{Introduction}

Mining is a sector of business which is always considered to contribute to economic growth in a region. It is an assumption that drove many Governments that provide a variety of ease licensing for the mining business to be able to operate. Economic choices that rely on mining, often ignoring the fact that the resulting economic growth unsustainable mining sector, and thus result in environmental damage and result in bad for health and robs the community living space that constantly occur. the potential negative impact of mining caused the mining venture characteristics taking the resources stored in the Earth, made by digging the soil to a depth of tens even hundreds of meters in the belly of the Earth, which causes a change in against the landscape, environment, and space of human living.

Mining permissions granted through regulation that is supposed to minimize damage to nature, the environment and people's lives due to mining. But the prerequisites set forth in the provisions of the law, in its implementation does not meet expected goals. As was the case in East Kalimantan province on the island of Kalimantan, Indonesia. There are 1,404 coal mining business license issued by the Central Government and the regions, with the mining area 
covering 5.2 million acres ${ }^{1}$. Mining affects the economy of East Kalimantan within a short time only about 10 years and the economy will go down even until minus $6 \%$ as well as the impact of damage to nature and the lives of the people. It also happens to a threat to the life of the community with the victims of the 29 , mostly children who drowned in a pit coal mine in East Kalimantan.

Problems that occur due to the operation of the mining company shows the occurrence of a violation of the basic human rights that are part of the provisions of human rights (human rights). Human rights is a fundamental right that is inherent to the human self is not supernatural, is universal and lasting, therefore it must be protected, respected, maintained, and should not be ignored, downplayed, or taken away by anyone. That view is appropriate in line with the Universal Declaration of human rights, at the United Nations on human rights mentioned: "Recognition of the inherent dignity and the equal and inacceptable rights of all member of the human family is the foundation of freedom, justice and peace in the world. ${ }^{2}$

Human rights are the most basic rights and attached to it wherever it is. if there are not human rights means that reduced its value as a human being. Human right is an assertion that can be morally justified, a thing that was supposed to get legal protection ${ }^{3}$. Unitary State of the Republic of Indonesia guarantees the welfare of everybody in their country, including the protection of the rights of the child which is a basic human right. The son is the mandate and the grace of God, which is inherent in their value and dignity as a whole person.

Human rights (human rights) is a right inherent in every human being, are fundamental and essential for a dignified life as human beings. Article 1 of LAW Number 39 Of 1999 on human rights. in this law the definition of human rights is a set of rights which is inherent in the nature and existence of man as a creature of God and His grace that must be respected, then protected by State laws and Government, not only that but also all the people should be protect the value and dignity of human being. Children's rights are part of human rights. The child's group who is vulnerable often experiencing acts of human rights violations. The rights of the child has been stated in the Geneva Declaration on the rights of the child the year 1924 and in the Declaration of the rights of the child approved by the General Assembly on 20 November 1959 has been recognized in the Universal Declaration of Human Rights, which, in the International Treaty on rights of economic, social and cultural, and then in the provisions and guidelines of the relevant execution device from the specialized agencies and the international organizations dealing with child welfare ${ }^{4}$.

Based on these considerations, which became important to review is the content of human rights including the rights of the child, not be as a precondition or the consideration of policy makers in the mining sector. The protection of HUMAN RIGHTS is not a consideration in the granting of permits, though the situation in the exploitation of the mine showed the occurrence of human rights violations. What kind of human rights violations and responsibility of the State case against children who drowned in a mine pit.

\footnotetext{
${ }^{1}$ Lampiran XI Perda Nomor 1 Tahun 2016 Tentang Rencana Tata Ruang Wilayah (RTRW) Provinsi Kalimantan Timur.

${ }^{2}$ Universal Declaration of Human Rights. 1948. The United Nation.

${ }^{3}$ Dalizar Putra, 1995, HAM Hak Asasi Manusia Menurut Al-Quran, Al-Husna Zikra, Jakarta, halaman 31 .

${ }^{4}$ Mukadimah CRC, Children Right Convention, Majelis Umum PBB, 20 November 1989
} 


\section{Reseacrh Problem}

The child is the next generation. losing a child is a totaly harm for the nation's future. Victims of children who were killed at the mine hole each year continues to grow, this is a humanitarian problem that should not be ignored. The child's right to life is part of human rights that are inherent and cannot be reduced (non-derogable) in its fulfillment. Permasalahn which will be examined in this paper deals with the children who drowned in a pit mine that is:

a. What kind of human rights violations in the case of children who drowned in a mine pit

b. How is the responsibility of the State case against children who drowned in a mine pit in the perspective of human rights?

\section{Research Methods}

The method used is the normative Legal research. This method is the legal research that aimed to find the solution of legal issues by way of researching the references or mere secondary data.

\section{Discussion}

\section{A. Dead Children Drowns In Coal Mine Pit}

\section{Human rights violations and State responsibility in the case of children who drowned} in the mine Pit

Rights of the child based on article 1 point (12) of law 39 of 1999 About HUMAN RIGHTS: rights of the child is part of the human rights that must be guaranteed, protected, and were met by parents, families, communities, countries, Governments, and local governments. The principle of the rights of the child based on the Convention on the rights of the child including the right to life, survival, and development of the child has the right to life of the child must get the care needed to ensure the physical, mental health, and their emotions as well as also the development of intellectual, social, and cultural.

The rights of children are part of human rights according to Article 52 section of 2: "Child's rights are human rights. in the interests of the child's rights, it is recognized and protected by law ever since in the womb. "Human rights violations according to Article 1 number (6) of Law 39 of 1999 concerning Human Rights, are any acts of a person or group of people including intentional or unintentional state apparatus or negligence which violates the law to reduce, obstruct, limit and or revoke human rights human person or group of people guaranteed by this law, and not getting, or worried not getting a fair and right legal solution, based on the applicable legal mechanism.

\footnotetext{
${ }^{5}$ www.unicef.org. diakses 26 mei 2017 pk 15.43
} 
All of the threats and bad actions that cause the loss of children's lives are the action that can not go unpunished. Based on a review of international and national human rights instruments, it is seen that there have been violations of human rights, especially the most fundamental rights for children, namely the right to life. The removal of one's right to life is a crime of humanity.

Table 1. Violation of Children's Rights based on International Human Rights Instruments in the Case of Children Drowning in the pit of coal mining

\begin{tabular}{|c|c|c|c|c|}
\hline \multirow[t]{2}{*}{ Rights are violated } & \multicolumn{4}{|c|}{ International Instruments that are violated } \\
\hline & $\begin{array}{l}\text { Universal } \\
\text { Declaration of } \\
\text { Human Rights }\end{array}$ & $\begin{array}{l}\text { International } \\
\text { Covenan on } \\
\text { Civil and } \\
\text { Political Rights } \\
(\text { ICCPR }) \\
\end{array}$ & $\begin{array}{l}\text { Convention on } \\
\text { The Rights of the } \\
\text { child (CRC) }\end{array}$ & $\begin{array}{l}\text { International } \\
\text { Covenan on } \\
\text { Economic, Social } \\
\text { and Cultural Rights } \\
(\text { ICESR) }\end{array}$ \\
\hline Right To Life & Article 3 & Article 6 & Article 4 (1) & \\
\hline Rights to get protection & Article 7 & Article 24 (1) & Article 3 (2) & \\
\hline Protection rights before the law & & Article 26 & & \\
\hline $\begin{array}{l}\text { State policy, the private sector must } \\
\text { consider the best interests of the } \\
\text { child }\end{array}$ & & & Article 3 (1) & \\
\hline Right to a healthy environment & & & & Article $11(1)$ \\
\hline
\end{tabular}

Reviewing the case of children who drowned in the pit of a coal mine, in a human rights perspective has violated its international human rights instruments. International human rights instruments using several analytical tools are Universal Declaration of Human Rights, International Covenan on Civil and Political Rights (ICCPR), Convention on The Rights of the child (CRC), serta International Covenan on Economic, Social and Cultural Rights (ICESR). (tabel 1)

The form of rights violated is the right to life, the right to protection, the right to protection before the law, the right of the child to formulate state policies, the private sector must consider the best interests of the child.

Table 2. Violation of the Children's Rights Based on the National Provisions of Human Rights The Case of Children who Drowned in the Pit of Coal Mining

\begin{tabular}{|c|c|c|c|c|}
\hline \multirow[t]{2}{*}{ Rights are violated } & \multicolumn{4}{|c|}{ National Human Rights Instrument } \\
\hline & Constitution 1945 & $\begin{array}{l}\text { Law of } 23 / 2002 \text { jo } \\
\text { law of } 35 / 2014 \\
\text { Concerning Child } \\
\text { protection }\end{array}$ & $\begin{array}{l}\text { Law of } 39 / 1999 \\
\text { Concerning } \\
\text { Human Right }\end{array}$ & $\begin{array}{l}\text { Law } 32 \text { of } 2009 \\
\text { concerning the } \\
\text { Protection and } \\
\text { Management of the } \\
\text { Environment }\end{array}$ \\
\hline Children's right to life & $\begin{array}{l}\text { Article 28A; } \\
\text { Article 28B (2); } \\
\text { Article 28 I (1) }\end{array}$ & Article 3 and 4 & $\begin{array}{l}\text { Article 4, } \\
9(1), 53(1)\end{array}$ & \\
\hline The right to live safely & & & $\begin{array}{l}\text { Article } 9(2) \\
\text { And } 35\end{array}$ & \\
\hline $\begin{array}{l}\text { Right to protection and } \\
\text { legal protection }\end{array}$ & $\begin{array}{l}\text { Article 28D (1), } \\
28 \mathrm{G}(1)\end{array}$ & & $\begin{array}{l}\text { Article } 5(3), 52(1) \\
\text { and (2), } \\
\text { Article } 29\end{array}$ & \\
\hline
\end{tabular}




\begin{tabular}{llll}
$\begin{array}{l}\text { The right to a healthy } \\
\text { living environment }\end{array}$ & Article 28H & Article 9 (3) & $\begin{array}{c}\text { Article 65 (1) } \\
\text { and 68 (b) }\end{array}$ \\
$\begin{array}{l}\text { Violation of the right to } \\
\text { obtain justice, file a } \\
\text { lawsuit, equality in law }\end{array}$ & Article 27 (1) & Article 5 (3) & \\
\hline
\end{tabular}

Violations of children's rights in the case of children who are drowning at the pits of Coal Mine, based on national and international human rights provisions/instruments are violations of children's rights that is :

\section{a. Children's right to life}

Article 3 of the Universal Declaration of Human Rights : "everyone has the right to life, liberty and security of person. Part 3 in Article 6 of the International Covenan on Civil and Political Rights (ICCPR) : "Every human being has the inherent right to life. This right shall be protected by law. No one shall be arbitrarily deprived of his life.

The right to life is a basic right in the ICCPR which is classified as rights in a nonderogable type, namely absolute rights which cannot be reduced by the fulfillment of the state parties, even if in an emergency. States that violate the rights of non-derogable types will be criticized as a country that has committed gross violation of human rights ${ }^{6}$. Provisions in the Convention on the Rights of the Child (CRC) of the Convention on the Rights of the Child. Indonesia has ratified through Presidential Decree No. 36 of 1990. Provisions Article 4 (1) recognizes that every child has inherent rights to life: "States Parties recognize that every child has the inherent right to life" ${ }^{7}$ (participating countries recognize that every child has rights that is attached to life).

Recognition of the right of life of every person in the Constitution of the Republic of Indonesia in Article 28A of the 1945 Constitution, namely that everyone has the right to live and has the right to defend his life and life. Article 28B (2) Every child has the right to survival, growth and development and has the right to protection from violence and discrimination. Article 28I (1) The right to life, the right not to be tortured, the right to freedom of thought and conscience, the right to religion, the right not to be enslaved, the right to be recognized as a person before the law, and the right not to be prosecuted on a retroactive law is human rights that cannot be reduced under any circumstances.

Article 3 of Law 23 of 2002 in conjunction with Law 35 of 2014 concerning Child Protection Child protection aims to ensure the fulfillment of children's rights in order to live, grow, develop and participate optimally in accordance with human dignity and dignity, and to be protected from violence and discrimination, for the sake of creating quality Indonesian children who are noble and prosperous. Article 4 of Law No.23 of 2002 jo. Law No. 35 of 2014 concerning Amendments to the Law on Child Protection Every child has the right to be able to live, grow, develop and participate naturally in accordance with human dignity and dignity, and to be protected from violence and discrimination.

Article 4 of Law 39 of 1999 concerning Human Rights. The right to life, the right not to be tortured, the right to personal freedom, mind and conscience, the right to religion, the right not to be enslaved, the right to be accepted as a person and equality before the law, and the

${ }^{6}$ Ifdhal Kasim, 2001. Hak Sipil dan Politik - esai-esai pilihan. Lembaga Studi dan Advokasi Masyarakat (ELSAM) Jakarta, halaman: xii

7 www.unicef.org/crc/ diakses 9 Desember 2017 pk. 13.33 Wite. 
right not to be sued on a retroactive law is human rights which cannot be reduced under any circumstances and by anyone.

Right to Life on Article 9 (1) Everyone has the right to live, maintain life and improve their standard of living. Article 53 (1) of the Human Rights Law "Every child from the womb, has the right to live, maintain life and improve his standard of living." The case of the sinking of children in the mine pit in East Kalimantan is a form of violation of the rights of children's lives, both violate international human rights instruments and national human rights instruments.

\section{b. The right to live safely}

Based on the provisions of human rights regulated by Law 39 of 1999 , everyone is recognized as entitled to live. even it is not only to live but also a life that guarantees a sense of security. This is in accordance with Article 9 paragraph (2) of Law 39 of 1999 concerning Human Rights. Everyone has the right to live in the system of society and statehood that is peace, security, peace, happiness, physical and spiritual prosperity. The existence of mine holes which are left without reclamation efforts includes the people who cannot live comfortably and safely. The threat of safety of children who are forced to live surrounded by dead holes, while playing facilities for children are not available. Article 35 of Law 39 of 1999, Everyone has the right to live in a peaceful, safe and peaceful society and state that respects, protects and fully implements human rights and basic human obligations as regulated in this law.

\section{c. Right to protection and legal protection}

The 1989 Convention on the Rights of the Child states children, because their physical and mental immaturity requires special protection and care, including proper legal protection, before and after birth. Article 3 (2) Convention on the Rights of the Child Participating countries seek to guarantee that children will receive protection and care as needed for their welfare, by paying attention to the rights and responsibilities of their parents, guardians or other individuals who are legally responsible for the child, and for this purpose, will take all legislative and administrative steps right. This provision is in line with the Universal Declaration of Human Rights article 7 "everyone is equal to the law and entitled to the same legal protection with no difference.

On the Article 24 paragraph (1) of the Convention on Civil and Political Rights (ICCPR), confirms the right of children to get protection from family, society and the state without discrimination: "Every child must, without discrimination based on ethnicity, color, sex, religion, the origin of nationality or social wealth or birth is given the right to all protection measures needed for his status as a minor, from the family, community and country.

The Convention on Civil and Political Rights (ICCPR), Article 26 states specifically that in addition to general protection for children there is a need for legal protection: "All people are equal before the law and entitled to the same legal protection without any discrimination. Regarding this law the law prohibits all discrimination and guarantee everyone the same and effective protection (effective).

The right to protection for children is also recognized by the Indonesian state constitution, Article 28D (1) of the 1945 Constitution, Everyone has the right to a recognition, guarantee, protection and legal certainty and equal treatment in the law. Article 28G (1) of the 1945 Constitution: Everyone has the right to personal, family, honour, dignity and property protection under his authority, and has the right to security and protection. 
Special protection for children is needed as a form of commitment to protect vulnerable groups, children are vulnerable groups, vulnerable in the sense that if a policy change is made, the lives of vulnerable groups will be directly affected by these changes. In the provisions of article 5 paragraph (3) protection of vulnerable groups is stated every person who belongs to a vulnerable group of people has the right to receive more treatment and protection with regard to their specificity. In the explanation of the article what is meant by vulnerable groups include the elderly, children, the poor, pregnant and disabled women.

Based on the provisions of article 52 paragraph (2) of the Human Rights Law which the rights of children are human rights, therefore, the rights of the child are recognized and protected by law ever since in the womb. Article 29 of the Human Rights Law (1) Every person has the right to the protection of his personal, family, honour, dignity and property.

\section{d. The right to a healthy living environment}

the rights to the healthy living environment are fundamental human rights. The right is inherent as that which strengthens the construct of human life ${ }^{8}$. The Rio Declaration on Environment and Development in 1992 emphasized that governments around the world have an obligation to commit to the fulfilment of human rights to a healthy and clean environment. Based on the Fourth Principle (Principle 4) of Rio Declaration: in order to achieve sustainable development, environmental protection shall constitute an integral part of the development process and cannot be considered in isolation from it. ",

The Indonesian Constitution states that a good and healthy environment is a human right. it is the constitutional right of every Indonesian citizen. Therefore, the state, government and all stakeholders are obliged to protect and manage the environment in the implementation of sustainable development so that Indonesia's environment can be a source of life for supporting the people of Indonesia and other living things.

based on to the provisions of Article $28 \mathrm{H}$ of the 1945 Constitution Every person has the right to live physically and mentally, live and obtain a good and healthy environment and has the right to obtain health services. Article 9 paragraph (3) Human Rights Law Everyone has the right to a good environment and health. Right to the environment Article 65 paragraph (1) of Law 32 of 2009 concerning Environmental Protection and Management: Everyone has the right to a good and healthy environment as part of human rights.

The environment intended is the provision in the article 1 point (1) of Law 32 of 2009 concerning the Protection and Management of the Environment: Unity of space with all objects, power, circumstances, and living things, including humans and their behavior, which affect nature itself, the survival of life and the welfare of humans and other living things.

e. Violation of the right to obtain justice, file a lawsuit, equality in law

The Indonesian Constitution recognizes that every citizen has the same position in the law, this provision is contained in article 27 paragraph (1) of the 1945 Constitution: Every citizen is simultaneously in the law and government and must uphold the law and government with no exception.

\footnotetext{
${ }^{8}$ Majda El Muhtaj, 2009. Dimensi-dimensi HAM, Mengurai Hak Ekonomi, sosial dan budaya, Rajawali Pers, Jakarta. Halaman : 204

${ }^{9}$ Michael Keating, 1992. The Earth Summit's Agenda for Change. Published by the centre for our common Future 52 rue des Paquis, 1201 Geneva, Switzerland. www.unesco.org. Diakses 9 desember 2015. Pk 13.05 Wite.
} 
on the Article 17 of Law Number 39 of 1999 concerning Human Rights, Everyone is without discrimination, has the right to obtain justice by submitting an application, accusation, and lawsuit, both in criminal, civil and administrative matters as well as being tried through a free and impartial judicial process, according with procedural law that guarantees objective examination by honest and fair judges to obtain fair and correct decisions.

\section{The Government's responsibility in the human rights perspective on cases of children drowning in the pit of coal mines}

Children need special care and protection, they depend on the aid adult, especially in the early years and their lives. It is not enough that children are given the same rights and freedoms as adults. Children themselves are unable to fight or change the conditions they experience effectively to be better. Therefore, effective action is needed to change things better for children ${ }^{10}$.

Table 3. The State responsibility specifically in the human rights perspective on cases of children drowning in coal mining pit

\begin{tabular}{|c|c|c|}
\hline No & The Form of Responsibility & Human right Instrument \\
\hline 1 & Responsibility to grant protection & $\begin{array}{l}\text { - Convention on The Rights of the child (CRC) } \\
\text { article } 3 \text { (2) } \\
\text { - Article } 20 \text { of Law } 23 \text { of } 2002 \text { in jo Law } 35 \text { of } \\
2014\end{array}$ \\
\hline 2 & $\begin{array}{l}\text { State policy, private sector must } \\
\text { consider the best interests of the } \\
\text { child }\end{array}$ & $\begin{array}{l}\text { - Convention on The Rights of the child (CRC) } \\
\text { Konvensi Hak Anak Pasal } 3 \text { (1) } \\
\text { - Article } 21 \text { of Law } 23 \text { Tahun } 2002 \text { jo Law } 35 \text { of } \\
2014\end{array}$ \\
\hline 3 & $\begin{array}{l}\text { The obligation of Guarantee the } \\
\text { survival and development of } \\
\text { children }\end{array}$ & $\begin{array}{l}\text { - Convention on The Rights of the child (CRC) } \\
\text { article } 6 \text { point (2), }\end{array}$ \\
\hline 4 & $\begin{array}{l}\text { The obligation to make children } \\
\text { rights implementation policies }\end{array}$ & $\begin{array}{l}\text { - Convention on The Rights of the child (CRC) } \\
\text { article } 4 \\
\text { - Law } 23 \text { of } 2002 \text { jo law } 35 \text { of } 2014 \text { on thr article } \\
21\end{array}$ \\
\hline 5 & $\begin{array}{l}\text { The obligation to conduct } \\
\text { surveillance }\end{array}$ & $\begin{array}{l}\text { - Law } 23 \text { of } 2002 \text { jo law } 35 \text { of } 2014 \text { on the } \\
\text { article } 23 \text { point } 2\end{array}$ \\
\hline 6 & $\begin{array}{l}\text { The obligation of Guarantee the } \\
\text { survival and development of } \\
\text { children }\end{array}$ & - $\quad$ article 71 and article 72 of law 39 of 1999 \\
\hline
\end{tabular}

according to Juridical, government legal responsibility in cases of children drowning in mine pits is:

\section{a. Responsibility to grant protection}

The right of children to get protection raises the obligation to fulfil these rights. Based on the Convention on the Rights of the Child (CRC) Convention on the Rights of the Child

10 C. de Rover. 2000, To Serve \& To Protect, Acuan Universal Penegakan HAM. Radja Grafindo Persada, halaman : 369 . 
Article 3 (2) : States parties undertake to ensure the child such protection and care as is necessary for their rights and duties of his or her parents, legal guardians, or other individuals legally responsible for him or her, and this right and all appropriate legislative and administrative measures.

The participating countries endeavour to ensure that the child will receive protection and care as needed for his welfare, taking into account the rights and responsibilities of his parents, guardians or other individuals who are legally responsible for the child, and for this purpose, will take all appropriate legislative and administrative steps.

Responsibility for child protection according to the Article of 20 in the Law number 23 of 2002 jo. Law Number 35 of 2014 concerning Amendments to the Law on Child Protection: States, governments, regional governments, communities, families and parents are obliged and responsible for the implementation of child protection. Child protection according to the Child Protection Act article 1 number (2) is all activities for guarantee and protect children and their rights in order to live, grow, develop and participate, optimally in accordance with human dignity and dignity, and to be protected from violence and discrimination.

The implementation of child protection is based on Pancasila and is based on the Constitution of the Republic of Indonesia in 1945 and the basic principles of the Convention on the Rights of the Child include non-discrimination; best interests for children; rights to life, survival and development; and respect for children's opinions.

On the article 52 paragraph (1) of the Human Rights Law, Every child has the right to protection by parents, family, society and the state. Based on these provisions, the parties, namely parents, family members and the state have an obligation to provide protection to children. This protection in the case of children drowning in a mine pit is certainly needed in a concrete way to make children no longer being victims.

\section{b. State policy, private sector must consider the best interests of the child}

That the best interests of children must be the main consideration, completely this provision is regulated in the Convention on the Rights of the Child (CRC) Convention on the Rights of the Child Article 3 (1) In all actions concerning children, whether it is carried out by public or private social welfare institutions, courts of law, administrative authorities or legislative.

The choice of regional development policies that allow the operation of mining companies in areas that can threaten children's lives is a proof of policy that is made without considering the best interests of the child. Even when children have become victims, there are not policies from the central or regional governments to overcome them.

\section{c. The obligation of Guarantee the survival and development of children}

On the Article 6 paragraph (2), the Convention on the Rights of the Child: Participating countries will guarantee to the maximum extent of child development and survival. This obligation is affirmed considering the survival of children will affect the dignity and civilization of the nation.

\section{d. The obligation to make children rights implementation policies}

Convention on the Rights of the Child Article 4, the participating countries will take all legislative, administrative and other steps for the implementation of the rights recognized in the Convention on the Rights of the Child. Responsibility of the government according to article 21 paragraph (4) : the Child Protection law To guarantee the fulfillment of the Rights of the Child and carry out the policies as referred to in paragraph (3), the Regional 
Government is obliged and responsible for implementing and supporting national policies in the implementation of Child Protection in the region. Paragraph (5) The policy as referred to in paragraph (4) can be realized through the efforts of the region's government to develop decent districts/cities for Children.

\section{e. The obligation to conduct surveillance}

According to the Law No. 23 of 2002 jo. Law No. 35 of 2014 concerning Amendments to the Child Protection Act, Article 23 paragraph (2) "States, governments and regional governments oversee the implementation of child protection.

\section{f. The obligation of Guarantee the survival and development of children}

Responsibility for fulfilling, upholding and advancing human rights. The obligation of Human Rights Fulfillment and Enforcement in accordance with Article 71 on Law 39 of 1999: The Government is obliged and responsible for respecting, protecting, enforcing, and advancing human rights regulated in this Law, other laws and international human rights law received by the Republic of Indonesia. The real form of the implementation of the obligations in question is an effective implementation in all sectors. Like the provisions of Article 72: The obligations and responsibilities of the Government as referred to in Article 71 include effective implementation steps in the fields of law, politics, economics, social, cultural, national security and other fields of defence.

\section{Close}

\section{a. Conclusion}

1) All of the threats and bad actions that cause the loss of children's lives are the action that can not go unpunished. Based on a review of international and national human rights instruments, it is seen that there have been violations of human rights. The removal of one's right to life is a crime of humanity. The rights of children who are violated are (1) Right to Life; (2) Right to Safe Life; (3) Right to Legal Protection; (4) Right to a healthy environment; (5) The right to obtain justice and equality in law.

2) The responsibility of the state in the case of a child sinking in a mine pit is (1) the obligation to provide protection; (2) Making a state policy, the private sector must consider the best interests of the child; (3) Ensuring child survival and development; (4) Making policies for the fulfillment of children's rights; (5) Supervision of Child Protection; (6) Meet, uphold and promote human rights.

\section{b. Suggestion}

1) The real action is needed to realize the protection of children's rights. Protection of children's rights is an important action and must be done immediately because protecting children is protecting the future of the nation and the future of civilization. Concern and concrete actions from various parties will be needed.

2) The government as soon as possible took concrete steps to ensure that were no more child deaths in the coal mining pit. the action against the person in charge of the ex- 
mine pit needs to be carried out so that accountability and reclamation of the mine pit are carried out.

3) The government should enforce the law against mining companies that have a responsibility to ex-mining pit that is not reclaimed and effect the loss of children's lives.

\section{Literature}

[1]. .de Rover. 2000, To Serve \& To Protect, Acuan Universal Penegakan HAM. Radja Grafindo Persada.

[2]. Dalizar Putra, 1995, HAM Hak Asasi Manusia Menurut Al-Quran, Al-Husna Zikra, Jakarta,

[3]. Ifdhal Kasim, 2001. Hak Sipil dan Politik - esai-esai pilihan. Lembaga Studi dan Advokasi Masyarakat (ELSAM) Jakarta.

[4]. Mukadimah CRC, Children Right Convention, Majelis Umum PBB, 20 November 1989

[5]. Majda El-Muhtaj, 2005. Hak Asasi Manusia dalam Konstitusi Indonesia. Kencana Prenada Media Group

[6]. Majda El Muhtaj, 2009. Dimensi-dimensi HAM, Mengurai Hak Ekonomi, sosial dan budaya, Rajawali Pers, Jakarta.

[7]. Michael Keating, 1992. The Earth Summit's Agenda for Change. Published by the centre for our common Future 52 rue des Paquis, 1201 Geneva, Switzerland. www.unesco.org. Diakses 9 desember 2015. Pk 13.05 Wite.

[8]. Universal Declaration of Human Rights. 1948. The United Nation.

[9]. http://www.blhd.kutaikartanegarakab.go.id/read/news/2014/162/banyak-kolam-galian-tambangbelum-direklamasi.html diakses 2 desember 2017. Pk. 14.42. Wite

[10]. www.unicef.org. diakses 26 mei 2017 pk 15.43

[11]. www.unicef.org/crc/ diakses 9 Desember 2017 pk. 13.33 Wite 